\title{
SECURITIZATION AGAINST SEX TRAFFICKING OF WOMEN AND CHILDREN: THE CASE OF MULTILATERAL COOPERATION IN THE MEKONG SUB-REGION
}

\author{
Jidapa Buayairugsa \\ Suan Sunandha Rajabhat University, Bangkok, Thailand
}

This research examines the securitization process and the effectiveness of multilateral cooperation against sex trafficking of women and children in the Mekong sub-region. It has been inspired by an open question of why the situation with sex trafficking has not improved despite the availability of a significant number of multilateral anti-trafficking mechanisms. The research analyses and evaluates anti-trafficking mechanisms of the ASEAN and COMMIT up to the mid of 2018 in the light of securitization theory and human security concept. The research concludes that anti-trafficking mechanisms within ASEAN and COMMIT have not yet adequately mitigated sex trafficking of women and children. Even though they have addressed trafficking in many different ways, some evidence shows that the ways in which they have proceeded with their anti-trafficking mechanisms have criminalized trafficked victims more than protected them. This practice is as a result of the state-centric policies instead of human-centric ones. Hence, regional mechanisms should prioritize human security and human rights when being employed to resolve security issues.

Keywords: securitization theory; human trafficking; multilateral cooperation; ASEAN; COMMIT; Mekong Sub-Region

\section{Introduction}

The Mekong sub-region is, sadly, recognized as the center of sex trafficking in Asia. There have been more than 200,000 women and children trafficked in the Mekong subregion (World Vision, 2005). This trafficking has concerned the international community as a human security issue because it entails negative effects on individuals' livelihood through obvious violation of human rights and spread of chronic diseases (Shelley, as cited in Kranrattanasuit 2014, 42). In the Mekong sub-region, many international organizations, regional organizations, governments and NGOs have already established multilateral cooperation to combat human trafficking. ASEAN and COMMIT have played prominent roles in counteracting this trafficking. Although they have developed many policies, legal

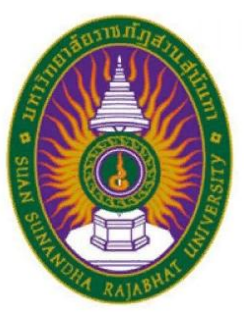

\section{Jidapa Buayairugsa}

Lecturer in College of Innovations and Management, Suan Sunandha Rajabhat University, Bangkok, Thailand

Science interests: economy and social regulation, administration, criminal law

E-mail: jidapa.bu@ssru.ac.th 
instruments and anti-trafficking institutions, they have not yet adequately addressed this issue. This article argues that anti-trafficking mechanisms established by the ASEAN and COMMIT prioritize state-centric approach over human security approach. These mechanisms do not actually consider human rights at all. Accordingly, they are ineffective when implemented to combat sex trafficking.

\section{Objectives}

1. This article aims to examine why the situation with sex trafficking prevention has not yet improved despite the significant number of multilateral anti-trafficking mechanisms.

2. This article aims to review the existing responses to sex trafficking by regional organisations (namely, ASEAN overall and COMMIT in particular).

3. This article aims to assess the effectiveness of each mechanism implemented by regional institutions in combating sex trafficking up to the mid-2018 initiatives.

\section{Literature review}

\section{The Nature of Sex Trafficking in Women and Children in Southeast Asia}

Southeast Asia is known as the hub of sex trafficking in women and children. According to the UNIAP's report, there are big difficulties with estimating the actual statistics of human trafficking in the Southeast Asia because of the difference in the definitions of trafficking. However, there are some agencies' reports showing that trafficking in Southeast Asia has been going in large numbers. Wuiling $(2006,54)$ stated that about 60 percent of the global trafficking occurs within the Southeast Asia. Furthermore, local Laos newspaper reported that 970 trafficked victims have been detected since 2001, and most of them were under 18.

Sex trafficking in this region is shaped by a number of social and economic factors. Peerapeng et al. (2012, 123) suggested that the major cause for sex trafficking is related to socioeconomic factors. While fast economic expansion has brought affluence to this region, it has created other problems to some areas such as health problems, environmental degradation and poverty. Sukma $(2010,8)$ also pointed out that poverty can be one of the key reasons for trafficking; claimed that poverty in Cambodia forces local people engage in sex trafficking. Although poverty affects both males and females, there are more poor females as compared to poor males. As a result, many Cambodian women are trafficked more than men.

Lack of education can also cause engagement of women and children in sex trafficking. A study by Le Thi Quy illustrates that there are large numbers of women with low education level in Vietnam because they have the motherhood burden. Also, the traditional concept, particularly in rural and mountainous areas, of "thinking highly of men and belittling women" forces women sacrifices their opportunities to privilege men. As a result, it is often harder for them to access education, and several studies have already confirmed that most women engaged in trafficking have very low level of education (2000, 56-57).

Another factor in human trafficking is the male-based demand in sex services. The demand for sex services provided to foreigners leads to an increase in sex tourism in many developing countries. As the UNODC's publication (n.d.) also states, Pattaya and Bangkok became the markets of prostitutes during the Second World War and then, during the 


\section{SECURITIZATION AGAINST SEX TRAFFICKING}

Vietnam War. Currently, they are still the widely popular centers for international sex tourism.

However, high domestic demand is also the root of trafficking women and children into the sex industry. In the case of Cambodia, many women and children are either forced or volunteer to work as prostitutes. They are assigned to service Khmer men and boys who are working away from homes such as soldiers, fishermen, and migrant laborers (IOM, 2000).

The review of causes behind sex trafficking will be helpful for evaluating the effectiveness of combating sex trafficking in this sub-region. This article employs this information to analyze whether anti-sex trafficking mechanisms can address the root causes behind sex trafficking.

\section{Securitization Theory and Human Security Concept as Theoretical and Analytical Framework}

Sex trafficking in women and children in the Mekong sub-region has been addressed by regional institutions and the governments of the Mekong Member States. However, the number of sex trafficking cases has not decreased. In order to examine the reasons for the above phenomenon, it is necessary to evaluate the effectiveness of anti-trafficking mechanisms within the Mekong sub-region. Securitization theory and human security approach are employed as an analytical framework that highlights strengths and weaknesses of the currently employed anti-trafficking mechanisms.

Securitization theory is used for finding the anticipated factors behind successes and failures of multilateral cooperation in the Mekong sub-region to counter sex trafficking because this theory helps tracing back the security discourse in the creation of anti-trafficking mechanisms, and spotlighting the political context behind anti-trafficking cooperation.

Securitization theory was developed by Barry Buzan and colleagues. According to this theory, security is "the move that takes politics beyond the established rules of the game and frames the issue either as a special kind of politics or as above politics" (Buzan et al., 1998, 23). Security issues are presented as an existential threat that demands emergency measures and actions upon the normal political procedure (Buzan et al., 1998. Hence, securitization is unlike politicization that the security issue tends to be a part of public policy, and needs normal political responses. Security issue will be successfully securitized when it obtains the acceptance from the audience. However, if it does not, it can be only a securitizing move (Buzan et al., 1998, 25).

According to Lozano-Vázquez (2015, 48), the ontology of securitization theory engages in post-foundationalism so that "facts, processes, and behaviours are socially constructed and depend on subjects' perceptions and interpretations". Hence, securitization studies are intersubjective rather than objective. Furthermore, the epistemology of securitization aligns with constructivism and poststructuralism. The poststructuralists assume that security can be understood as a political discourse (Hansen, 2007, 35). Also, "policies draw upon representations of identity linking to a conceptualization of identity as discursive, political, relational and social" (Hansen, 2007, 6). According to Hansen's argument, foreign policies need to "ascribe meaning to the situation and to construct the object within it, and in doing so they articulate specific identities of other states, regions, people, and institutions as well as on the identity of national, regional, or institutional Self". Therefore, when agents prioritize an issue as a security issue that need extraordinary measures, it means they are creating political security discourse through institutional practices. 
Securitization theory examines security discourses in order to "understand the processes of constructing a shared understanding of what is to be considered and collectively responded to as a threat" (Buzan et al., 1998, 26). The way to study security discourse is not evaluating "objective threats", but it is to examine "speech act". Speech act is a category originating from the language theory. Security analysts use this word to represent the process of securitization (Buzan et al., 1998, 26). Thus, studying speech act (the process of securitization) means examining "the political use of language by focusing on a very specific aspect of human interaction, namely, the social construction of security issue, and even more specifically, the "power politics of concept" (Buzan et al., 1998).

In addition, human security concept is utilised for examining the shortcomings of the current approaches embedded in anti-trafficking mechanisms. Human security is an approach to security analysis that emphasizes a close relationship between human rights and development concerns with people's lived experiences of security. Hence, this thesis evaluates the policies and actual implementations of the human security concept and human rights' based approach. It is argued that human security and human rights framework should be included in the formulation of any policy developed to counter sex trafficking.

The concept of human security was originally defined in the 1994 United Nations Development Program (UNDP)'s report as "a safety from chronic threats such as hunger, disease, and repression as well as protection from sudden and harmful disruptions in the pattern of daily life" (Acharya \& Acharya, 2002, 326). The human security concept emerged after the end of the Cold War because of the increase in intra-state conflicts threatening to the quality of individuals' life. As a result, scholars and policy makers attempted to resolve the threats by connecting security to development.

Followers of the human security approach can be divided into two camps. The first one is the Japanese approach, which is defined as the agenda of 'freedom from want'. Human insecurity from this perspective will be the issue concerning the violation of human rights, transnational organised crime, refugees, poverty, infectious diseases and/or environmental degradation (Pitsuwan \& Caballero-Anthony, 2014, 202). The second approach to human security is the approach adopted by the Canadian government. It focuses on "the security of the individual as opposed to the state, but their primary emphasis is on security in the face of political violence". It can be understood as the agenda of 'freedom from fear' (Kaldor, 2007, 183).

Alkire (2003, 36-37) pointed out that human security and human development are both people-centred concepts. Both of them "address people's dignity as well as their material and physical concerns". Moreover, the definition of human security can be interpreted "in a manner that is consistent with long-term human development". Also, both concepts aim to address chronic poverty.

However, there are distinctions in the scope between human security and human development. Firstly, the human security concept seems to be narrower than human development. "Human security includes a strictly delimited subset of human development concerns, but excludes much of human development as lying outside its own mandate (Alkire, 2003, 36). Additionally, "policies for human security seek to create the capacities required to prevent, mitigate, or cope with threats that would cut into people's vital core such as AIDS prevention, social security, including terrorism and new securities. Nevertheless, the objective of human development concerns only growth with equity" (Sen, 2000). Lastly, many projects addressing human security problems have taken place within a very short time 


\section{SECURITIZATION AGAINST SEX TRAFFICKING}

while most of human development projects have occurred in a longer term, thus investing in institution-building and capacity-building (Alkire, 2003, 37).

Human rights are related to the human security approach. Many studies about human security have adopted "a human rights stance: the basic requirements of no individual are to be sacrificed". As Alkire $(2003,38)$ wrote, "the identification protection and promotion of central facets of human lives from the 'freedom from fear' and 'freedom from want' is the aim of human security as well as of human rights". However, Alkire states that human security practitioners use economic, political and perhaps military forces and try to realise human security with the same force and decisiveness that characterises national security efforts. In contrast, human rights activists employ legal instruments to prevent human rights' abuse (Alkire, 2003, 40). Although there are differences between these concepts, Alkire proposed that human rights and human security should complement rather than work against each other $(2003,40)$.

\section{Methodology}

This article aims to illustrate the securitization process of sex trafficking and to evaluate anti-trafficking mechanisms established by regional institutions (namely, ASEAN and COMMIT) through securitization theory and human security approach. These approaches help spotlighting how regional institutions have interpreted sex trafficking as a regional security issue, highlighting the role of politics, strengths and weaknesses of antitrafficking mechanisms in the sub-region in question.

This article employs discourse analysis for analysing the languages and signs existing in policy documents, law papers, MoU papers, declaration and convention papers, plan of action papers, press releases, anti-trafficking practices related to prosecution of criminals, protection of victims, repatriation and reintegration, prevention of trafficking and participation of CSOs/ NGOs in advocacy.

The analysis in this research is based on the analytical framework of (Buzan et al., 1998). There are 3 levels of securitization analysis. It begins with engaging women and children affected by sex trafficking as the referents of security. Then, it studies regional institutions (ASEAN, COMMIT) as securitizing actors. As well, other functional actors are defined, including the UN, the US government, CSOs and NGOs, all of them are also covered by the analysis. This research goes further to evaluate anti-trafficking mechanisms under human security and human rights approach.

\section{Results}

The ASEAN in general and COMMIT in particular have taken the important role in combating sex trafficking in women and children in the Mekong Sub-region. Both of them have securitized trafficking as a regional security problem that needs urgent measures to be taken at the regional level. The ASEAN has also securitized trafficking as a transnational crime threatening regional/state security, while COMMIT has situated human security and human rights agenda into its general agenda. Consequently, COMMIT seems to have reached some more progress in eliminating trafficking, as compared with the ASEAN. However, state-centric vision is maintained by both ASEAN and COMMIT. This results in the overall inefficiency of anti-trafficking mechanisms of these organizations. Their understanding of 
the notions of consensus, consultation and sovereignty obstructs ASEAN from effectively mitigating sex trafficking. Additionally, reluctance in implementing projects under human security approach of the ASEAN and COMMIT Member States contributes to the ineffectiveness of multilateral cooperation when it comes to combating sex trafficking.

\section{Conclusions and Discussion}

This article concludes that anti-trafficking mechanisms within ASEAN and COMMIT have yet adequately mitigated sex trafficking in women and children. Even though they have addressed trafficking in many different ways, the most recent evidence shows that the ways they have preceded with their anti-trafficking mechanisms have in fact criminalized trafficked victims instead of protecting them. This practice has become the result of the statecentric vision dominance over basic human security priorities embedded in the policies of ASEAN and COMMIT. We insist that the local governments should prioritize more strongly the issues of human security and human rights while trying to resolve security issues related to trafficking in women and children.

\section{Suggestions}

The main purpose of this article is not to provide policy recommendations. Notwithstanding, it aims to spotlight that regional organizations (namely - ASEAN and COMMIT) and their separate member states have securitized and addressed sex trafficking through state-centric framework primarily. It is clear that this framework leads to serious weakness of anti-trafficking mechanisms at both regional and national levels. Therefore, it would be better if the governments in question change their way thinking about security issues, and also their norms about human security and human rights. The involved governments should also prioritize human security and human rights when trying to fight and prevent human trafficking in women and children.

\section{Acknowledgement}

The author would like to thank Assoc. Prof. Dr. Luedech Girdwichai, The President of Suan Sunadha Rajabhat University, Bangkok Thailand and also Asst. Prof. Dr. Bundit Pungnirund, The Dean of the College of Innovation and Management for their full support provided to this research.

\section{References:}

Acharya, A. \& Acharya, A. (2002). Human Security in Asia: Conceptual Ambiguities and Common Understandings, Man and Development (India). Accessible at: http://www.hegoa.ehu.es/dossierra/seguridad/Human_security_in_Asia_conceptual_ambiguitie s_and_common_und.pdf.

Alkire, S. 2(003). A conceptual framework for human security. Accessible from: http://www3.qeh.ox.ac.uk/pdf/crisewps/workingpaper2.pdf .

Buzan, B., Wæver, O., \& Wilde J.D. (1998). Security: a new framework for analysis. Accessible at: https://www.uni- 


\section{SECURITIZATION AGAINST SEX TRAFFICKING}

erfurt.de/fileadmin/public/Internationale_Beziehungen/BA_Einfuehrung_in_die_IB/BUZAN\% 20+\%20WAEVER+\%20WILDE_\%201998_Security_CH\%201+2.pdf .

Hensen, L. (2007). Security as practice: discourse analysis and the Bosnian War. Routledge, New York, NY.

Human Rights Watch (2014). World Report 2014: Cambodia. Accessible at: https://www.hrw.org/world-report/2014/country-chapters/cambodia .

International Organization for Migration (IOM) (2000). Combating trafficking in South-East Asia: a review of policy and programmer responses. Accessible at: http://www.unesco.org/most/migration/ctsea.pdf .

Kaldor, M. (2007). Human Security, In: M. Kaldor (ed.), Human Security. Polity Press, Cambridge.

Kranrattanasuit, N. (2014). ASEAN and human trafficking: Case studies of Cambodia, Thailand and Vietnam. Koninklijke Brill NV, Leiden.

Lozano-Vázquez, A. (2015). Desecuritization in theory and praxis: reestabilshing priorities of the hemisphere, In: B.M. Bagley, J.D. Rosen \& H.S. Kassab (ed.), Reconceptualizing security in the Americas in the twenty-first century. Lexington Books, London.

Peerapeng, S., Chaiti P. P., Chaiboonsri C., Kovacs S. \& Balogh P. (2012). Impact of Economic Globalization on the Human Trafficking in the Greater Mekong Sub-Region Countries. Scientific Papers. Accessible from: http://ageconsearch.umn.edu/bitstream/147426/2/20_SukRutai_Impact_Apstract.pdf .

Pitsuwan, S. \& Caballero-Anthony, M. (2014). Human Security in Southeast Asia: 20 Years in Review. Asian Journal of Peacebuilding, 2: 199-215.

Sen, A. (2000). Why Human Security? Accessible at: http://www.ucipfg.com/Repositorio/MCSH/MCSH-05/BLOQUE-ACADEMICO/Unidad01/complementarias/3.pdf .

Sukma, R. (2010). ASEAN and non-traditional security. Accessible at: http://www.wasedagiari.jp/sysimg/imgs/20101203_2c_sukuma_paper.pdf .

United Nations (UN) (2000). Protocol to Prevent, Suppress and Punish Trafficking in Persons, Especially Women and Children, Supplementing the United Nations Convention Against Transnational Organised Crime. Accessible at: http://www.osce.org/odihr/19223?download=true .

World Vision (2005). Companion handbook on anti-trafficking in children and women. Ha Noi.

Wuiling, C. (2006). Assessing Criminal Justice and Human Rights Models in the Fight against Sex Trafficking: A Case Study of the ASEAN Region. Essex Human Rights Review, 3,1.

Paper submitted

Paper accepted for publishing

Paper published online
22 May 2019

08 July 2019

08 August 2019 